\title{
苓桂五味甘草湯の適応病態に関する一考察
}

\author{
寺澤 捷年 ${ }^{\mathrm{a}}$ 横山 浩一 $\mathrm{b} \quad$ 小林 亨 $\mathrm{c}$ \\ 植田 圭吾d 地野 充時a \\ a 千葉中央メデイカルセンター和漢診療科, 千葉，＝264-0017 千葉市若葉区加曽利町 1835-1 \\ b 証クリニック, 東京, $\mathrm{T} 101-0052$ 千代田区神田小川町3丁目11 \\ c 星総合病院脳外科, 福島, $=963-8501$ 郡山市大町2-1-6 \\ d 千葉大学大学院医学研究院和漢診療学, 千葉， =205-2013 千葉市中央区亥鼻1-8-1
}

\section{On Clinical Findings and Indications for Ryokeigomikanzoto}

\author{
Katsutoshi TERASAWA $^{\mathrm{a}}$ Koichi YOKOYAMA $^{\mathrm{b}}$ Toru KOBAYASHI $^{\mathrm{c}}$
}

Keigo UEDA ${ }^{\mathrm{d}} \quad$ Atsushi CHINO $^{\mathrm{a}}$

a Department of Kampo Medicine, Chiba Central Medical Center, 1835-1 Kasoricho, Wakaba-ku, Chiba, Japan

b Akashi Climic, 3-11 Kanda-ogawacho, Chuo-ku, Tokyo, Japan

c Department of Neuro-Surgery, Hoshi General Hospital, 2-1-16 Koriyama, Fukushima, Japan

d Department of Japanes-Oriental (Kampo) Medicine, Graduate School of Medicine, Chiba University, 1-8-1 Inohana, Chuoku, Chiba, Japan

\begin{abstract}
Ryoukeigomikanzoto is a Kampo formulation originally described in the text Kinkiyouryaku. This formulation has also been described as an indication for respiratory disease in some texts, because it was classified under respiratory diseases in the Kinkiyouryaku.

The authors, however, considered that indications for ryoukeigomikanzoto could be wider than previously thought. The composition of this formulation is very similar that of ryokeimikanto and ryokeijutsukanto. And we have prescribed ryokeigomikanzoto for patients with a reddish face and coldness of the legs, whose chief complaints were a reddish nose, coldness of the leg, dysuria, spioncerebellar degeneration and ringing of the ears. Moreover, we have obtained good results from the current trial. This report is intended to elucidate indications for this formulation by means of past clinical results and our own experience.

Key words : ryokeigomikanzoto, ryokeimikanto, coldness of legs, dysuria, spinocerebellar degeneration

要旨

苓桂五味甘草湯は『金匱要略」所載の方剤であるが，痰飲咳嗽篇に記されているためか，幾つかの成書は咳嗽を 使用目的としている。しかし, 筆者らはこの方剤が苓桂甘震湯, 苓桂术甘湯と構成生薬が一味異なっていることか ら, その応用範囲はより広沉なものではないかと考えた。そこで, 顔面の紅潮と下肢の泠えを目標に, 鼻周囲発赤, 下肢冷感, 排尿困難症, 脊随小脳変性症, 耳鳴の症例に用いたところ, 効果が得られたので, それらの概略を記し た。また，この方剤の適応となる病症の容を文献的考察も併せて考察した。

キーワード：苓桂五味甘草湯，苓桂味甘湯，下肢冷感，排尿困難症，脊䯣小脳変性症
\end{abstract}

\begin{abstract}
緒言
苓桂五味甘草湯（苓桂味甘湯）は『金貴要略』痰 飲咳嗽病脈証治第十二11 に収載されている方剤であ る。この痰飲咳嗽病篇という分類に制約を受けたた めであろうか, 幾つかの成書には咳嗽を目標に応用 すると記されている。今回, 筆者らは「咳嗽」を離 れて, 条文中の「其面䧻熱, 如酔状。因復下流陰 股」に着目して様々な病症に応用したところ，良好 な結果を得たので文献的考察と併せてその適応病態
\end{abstract}

について報告する。苓桂五味甘草湯証に関する初め ての概括的検討である。なお，ここで用いた苓桂五 味甘草湯の構成生薬・分量は本文の末尾に附記した。

\section{症例}

症例 $1: 61$ 歳, 女性。

主 訴：顔面鼻稜旁部の暗赤色発赤。

現病歴: 2 年前から顔面の中央部 (鼻稜旁部 - 鼻 孔）が発赤し，ときに瘙痒を伴った。皮膚科で副腎 皮質ホルモン合剤（エンペラミン® ${ }^{\circledR}$, ミノサイクリ 
ン塩酸剤 (ミノペン $\left.{ }^{\circledR}\right)$, ベタメサゾン酪酸エステル プロピオン酸エステル軟亳 (アンテベート $\left.{ }^{\circledR}\right)$ で加 療されていたが無効であった。

現 症: 身長156 cm, 体重 $51.4 \mathrm{~kg}$, 血圧124/78 $\mathrm{mmHg}$, 体温 $36.4{ }^{\circ} \mathrm{C}$ 。

漢方医学的所見：顔面全体が紅潮しているが，特 に鼻稜旁部は暗赤。落屑や滲湿は認めなかった。手 は冷えないが，下肢の冷えを訴えた。自汗傾向。脈 候は浮数実。舌候は紫赤・微黄苔, 腹候は腹力中等 度で右臍傍圧痛の他には胸脇苦満などは認めなかっ た。口渇はなく，二便に異常なし。

経 過：顔面の紅潮を目標に苓桂五味甘草湯を投 与したところ，4 週間後に顔面紅潮は半減した。こ の間，1日服用を怠ったら翌日，劇しい瘙痒が起 こったということであった。3カ月の投与で, 鼻稜 旁部の暗赤皮膚病変も消失した。

症例 $2: 42$ 歳, 女性。

主 訴：下肢の冷痛 (左>右)。

既往歴：14歳時に左大腿骨骨髄炎。

現病歴：数年前から，特に誘因と思われることな しに，冬期になると顔面が著しく紅潮するように なった。これに伴い下肢は膝から下が泠えて痛むと いう。

現 症：身長 $160 \mathrm{~cm}$, 体重 $68.2 \mathrm{~kg}$, 血圧 $134 / 86$ $\mathrm{mmHg}$, 体温 $36.7^{\circ} \mathrm{C}$ 。

漢方医学的所見：顔面は酔状の如く紅潮していた。 手の冷えはないが, 下肢は膝から遠位部が他覚的に も冷えていた (左>右)。自汗傾向があり, 手掌· 足蹠に発汗を認めた。脈候は浮沈中間で細弱。舌候 は正常紅・腫大・白黄苔。腹候は腹力中等度で心下 㾂鞕を認めた。口渇はなく，二便に異常はない。

経 過: 苓桂五味甘草湯を投与。投与 4 週間で顔 面の紅潮は半減したが，下肢の冷えは僅かに改善し たのみであった。しかし, 痛みは感じなくなった。 8 週間で下肢の冷えが改善。TANITA デジタル温度 計 TT508による顔面眉間部と左下肢第 $1 \cdot 2$ 趾間部 の温度は初診時 $32.3{ }^{\circ} \mathrm{C} / 26.2{ }^{\circ} \mathrm{C}$ であったが， 8 週間 後には $31.2{ }^{\circ} \mathrm{C} / 28.2{ }^{\circ} \mathrm{C}$ となっ。

症例 $3: 65$ 歳, 男性。

主 訴：排尿困難。

現病歴： 5 年前から首・慰部・腰部痛があり, 下 肢のこむら返りが出現。 1 年前から排尿困難が顕著 となり, 泌尿器科を受診。良性前立腺肥大症の診断
の下に，シドロシン (ユリープ $\left.{ }^{\circledR}\right)$, ジスチグミン (ウブレチド®) の投与を受けたが無効で, 紹介受 診となった。

現 症：身長 $166 \mathrm{~cm}$, 体重 $68.2 \mathrm{~kg}$, 血圧 $142 / 88$ $\mathrm{mmHg}$, 体温 $36.6{ }^{\circ} \mathrm{C}$ 。

漢方医学的所見：顔面酔状の如く紅潮し, 頭冒感 があり，下肢は著しい冷えを認めた。手の冷えはな く, 自汗傾向も認めなかった。脈候は浮沈中間, 虚 実中間。舌候は正常紅 - 白黄苔。腹候は腹力中等度 で平腹。胸脇苦満などは認めなかった。口渴はなく， 便秘もないが，排尿困難で淋瀝し，排尿に数分間を 要した。首・熨部・腰部痛があり, 下肢のこむら返 りが頻発していた。

経 過：苓桂五味甘草湯を投与し，下肢の病攣が 著しい場合に備え药薬甘草湯エキスを処方した。4 週間で明らかな下肢の暖まりを自覚し, 排尿困難も 半減した。药薬甘草湯エキスは一服も用いずに済ん だという。 8 週間後，排尿困難が明らかに改善し 「この10年間，こんなに気持ちょく排尿出来たこと はない」と言う。なおこの間，泌尿器科から処方さ れていたシドロシン，ジスチグミンは併用していた。 12 週後, 顔面紅潮は消失。排尿障害はもとより, 腰 部 ・臀部痛も改善した。初診時の顔面眉間部と下肢 第 $1 \cdot 2$ 趾間部の温度は $33.5{ }^{\circ} \mathrm{C} / 26.0{ }^{\circ} \mathrm{C}$ であったが, 12 週間後には $32.2^{\circ} \mathrm{C} / 29.7{ }^{\circ} \mathrm{C}$ であった。なお, 同様 の排尿困難が苓桂五味甘草湯で改善した例を経験し ている(72歳，男性)。

症例 $4: 64$ 歳, 男性。

主 訴: 脊髄小脳変性症による失調性言語と躯幹 失調。

現病歴：約 7 年前から歩行時のふらつきとしゃべ りにくさが出現。徐々に進行し, 神経内科医院で脊 䯣小脳変性症の診断を受けたが，有効な薬剤はない とのことで紹介受診となった。失調性の発語障害と 運動失調があり，杖歩行で来院。

現 症: 身長 $161 \mathrm{~cm}$, 体重 $55.3 \mathrm{~kg}$, 血圧 $132 / 78$ $\mathrm{mmHg}$, 体温 $36.7{ }^{\circ} \mathrm{C}$ 。失調性言語障害のため,「ラ 行音」の発語が特に拙劣で言葉が聞き取りにくい。 杖歩行で躯幹失調も認めた。

漢方医学的所見：顔面が著しく紅潮しており，下 肢の冷感を認めた。手の冷えはなく, 自汗傾向も認 めなかった。脈候は浮沈中間, 虚実中間で大。舌候 は正常紅・微黄苔。腹候は腹力やや弱。臍上悸を認 
めた。口渇はなく，二便に異常はない。

経 過: 苓桂五味甘草湯を投与。 4 週間後, 「す ごく良い。呂律が回りやすくなり, 会話も楽になっ た。ほんとうにビックリした」と言う。「ラ行音」 を発語して貫うと, 初診時と比較して明らかに改善 していた。歩行失調に著変はないが, 視診では躯幹 動摇が軽減していた。12週後「すごく嬉しい。足も 温まった」と言い, 顔面の紅潮も軽減した。初診時 の顔面眉間部と下肢第 $1 \cdot 2$ 趾間部の温度は34.2 ${ }^{\circ} \mathrm{C} / 26.4{ }^{\circ} \mathrm{C}$ あ゙ったが，12週間後には32. $2{ }^{\circ} \mathrm{C} / 30.4$ ${ }^{\circ} \mathrm{C}$ あ゙った。

症例 $5: 57$ 歳，男性。

主 訴: 耳鳴と足の冷え。

現病歴：20年前から左の（キーンという）耳鳴が 出現, 半年前から右耳にも出現した。次第に音が大 きくなり，耳の塞がった感じがすると言う。下肢が 冷え, 靴下を履いて寝ており, 常時, 腰に使い捨て カイロを 3 枚貼っているとのことであった。

現 症: 身長 $160 \mathrm{~cm}$, 体重 $72.1 \mathrm{~kg}$, 血圧119/73 $\mathrm{mmHg}$, 体温 $36.7{ }^{\circ} \mathrm{C}$ 。聴力検査の結果は $1000 \mathrm{~Hz}$ で 右耳 $30 \mathrm{db}$, 左耳 $40 \mathrm{db}$ の低下, $4000 \mathrm{~Hz}$ で左耳 $30 \mathrm{db}$, 右耳 $45 \mathrm{db}$ の低下を認めた。

漢方医学的所見：顔面が紅潮し酔状のようであっ た。手の冷えはなく, 自汗の傾向を認めた。脈候は 細弦。舌候は正常紅 ・ 微白苔。腹候は腹力中等度で 右胸脇苦満を認めた。口渇はなく, 二便に異常はな い。

経 過：顔面の紅潮と頭冒感を目標に苓桂五味甘 草湯を投与した。 4 週間後, 左耳の耳鳴りは半減し, 同時に両耳の閉塞感は無くなった。使い捨てカイロ は不要となり, 靴下を履いて寝ると, いつの間にか 脱いでしまっているとのことであった。 8 週間後の 聴力の再検査では $1000 \mathrm{~Hz}$ で右耳 $20 \mathrm{db}$, 左耳 $30 \mathrm{db}$ の低下, $4000 \mathrm{~Hz}$ で左耳 $15 \mathrm{db}$, 右耳 $30 \mathrm{db}$ の低下と 改善を認めた。

\section{考察}

『金實要略』の苓桂五味甘草湯についての記述は 「青竜湯下已。多唾口燥。寸脈沈尺脈微。手足厥逆。 気従小腹。上衝胸咽。手足痺。其面拿熱如酔状。因 復下流陰股。小便難。時復冒者。与获苓桂枝五味甘 草湯。治其気衝 (1)である。吉益東洞は『方極』にに「治 心下悸，上衝，咳而急迫者」と記している。尾台榕 堂『類聚方広義』には「此の方，苓桂术甘草湯とは，
僅かに一味を易にするのみ。故に其の症も亦略相似 たり。学者宜しく其の方意を意会して, 以て之を施 すべし」と記されている。この記述は，本方は『金 貫要略』の痰飲咳嗽篇に所載のものではあるが，咳 嗽という症状に捕らわれることなく, 気の上衝に着 眼して，幅広く活用すべき方剤であることを示唆し ている。

この点に注目して成書を歴観すると, 『勿誤薬室 方函口訣』) 、医界之鉄椎』，『臨床応用 - 漢方処方 解説』6) 『漢方臨床ノート・治験篇』に には本方の記 述は無い。一方, 呼吸器疾患への応用に限局した記 述をしているものとして, 奥田謙蔵『漢方古方要方 解説』8), 山田光胤『漢方処方応用の実際』9がある。 さらに本方は呼吸器疾患に限らず, 気逆, 頭冒感, 上熱下寒などに着目して広く応用できるとの記述は 『皇漢医学』に認められるが，これは上述の『類 聚方広義』から導かれたものと考えられる。筆者ら の見解と同じ立場から, 具体的な臨床応用を記述し たのは大塚敬節である。『漢方と漢薬』誌を調査し たところ，大塚敬節 ${ }^{11}$ は1938年に感冒後の耳閉感に 本方を応用し，さらに1940年には滲湿性中耳 炎12)，1941年に顔面のカブレ・掻痒の症例を記して いる ${ }^{13)}$ 。『漢方診療三十年』 $\rrbracket^{14)}$ (1959年刊）には中耳 炎に本方が奏効した症例が記されている。この書籍 に影響を受け, 諏訪重雄 ${ }^{15)}$ は治験・不治験例を記述 している。これとほぼ同時期（1959年）に，龍野一 雄は『新撰・類聚方』著しているが，本書には 苓桂五味甘草湯の広汎な応用が詳細に記されている。 龍野による，その具体的な症例報告は気管支喘息に 不正子宮出血を合併した一症例である ${ }^{17)}$ 。日本東洋 医学会学術総会・抄録として, 嘔気 · 頭痛 ${ }^{18}$, 胸痛 ・呼吸困難 ${ }^{19)}$, 耳閉塞感 ${ }^{20)}$ を調査し得たが, 概括的 な本方についての論説はこれまでに無い。

そこで筆者らは，これまでの報告症例と自験例か ら, 苓桂五味甘草湯証について概括的な考察を加え たい。苓桂五味甘草湯は苓桂术甘湯, 苓桂甘呆湯と は一味の相違である。従って共通する症候と特異的 な症候がある。共通する症候は気逆である。本方の 条文に「気従小腹。上衝胸咽」と記される所以であ る。しかし, 発作性の衝逆は苓桂甘栜湯に特徴的で あり, 苓桂五味甘草湯の場合は持続的なもので, 「其面鿖熱如酔状」が本方の最も重要な目標となる。 「手足厥逆」,「因復下流陰股」とあるが，動的に冷 
えが下降して行く症例は未だ経験していない。しか し，下肢の泠えは本方証には必発で，これが主訴と なることがある（症例 2 )。「時復冒者」とあるよう に，頭冒感や耳の閉塞感も高頻度でみられる。大塚 敬節が記しているように，この兆候は問いかけて初 めて明らかになることがあるので，注意が必要であ る。

これまでの症例報告を読むと「小便難」を「小便 不利」と混同しているものがある。「難」は諸橋較 次『大漢和辞典』によれば「かたい。むつかし い」が本義であり,「困難」という用語の「難」で ある。従って「小便難」は排尿困難, 排尿障害を意 味する。他方,「小便不利」は基本的には尿量減少 を意味する。本方が排尿困難に有効なことは症例 3 に記したとおりである。

以上のことと臨床経験から本方証を箇条書きにす ると：

1）顔面に明らかな紅潮があり，時に頭冒感や耳 閉塞感を伴う。

2）下肢に自覚的，かつ/または，他覚的な冷え がある。

3 ）排尿困難を伴う事がある。尿量は減少傾向で ある。

4 ）便通は正常で下痢・便秘はなく，腹痛を伴う 事はない。

5 ）体温，血圧はほぼ正常範囲内である。

6 ）時に焦燥感，あるいは軽いパニック症状に襲 われることがある。

7 ）腹力は様々であるが, 極虚ではなく, 冷えを 触知することはない。

8 ）凍瘡罹患傾向はない。

さて，条文に戻って問題となるのは「寸脈沈尺脈 微」の記述である。これまでの報告で脈が沈・微・ 細を示したものは 9 症例中 8 例である。しかし, 今 回の筆者らの経験では脈沈に該当するものはなかっ た。しかし次のように推測すると，脈の性状は様々 であって良いと考えられる。そもそも本方証におけ る顔面の紅潮，下肢の冷え（時に四肢の冷え）, 排 尿困難がなぜ出現するのか。これは自律神経系，特 に交感神経系の不調に起因するように考えられる。 従来，交感神経系と副交感神経系と一括して述べら れているが, 交感神経系は多数の交感神経節の存在
からも理解されるように，全身が一律に制御される ものではないのである222。推測ではあるが，腸骨動 脈から下肢血管に分布する交感神経（上・下神経 叢）が過剩に活動している病態が本方証の根本であ る。さらに上腕動脈系の交感神経活動が優位になる と,「手足厥逆」の病態が形成され，「寸脈沈尺脈 微」となる。この推論を支持する材料として「小便 難」を本方が改善したことが挙げられる。尿道括約 筋はアドレナリン作動性 $\alpha$ 受容体を有しており, 交感神経系の過剰な働きは排尿困難を増悪させるの である。この尿道括約筋の過剩収縮を苓桂五味甘草 湯は解除するのである。

四肢が体温制御において冷却装置の役割を果たし ており, また，寒冷被曝に対して反射性に四肢の血 管収縮が起こるが，この反射性血管収縮と放熱シス テムの作動不調のために生じた病態が苓桂五味甘草 湯証であると理解することが出来る。すなわち，下 肢（時に四肢）血管の過剩収縮によって放熱が妨げ られた結果，代償性に顔面・頭部の表在血管は拡張 し，放熱を図ろうと努力する。これが「其面翕熱如 酔状」を呈すると考えられるのである。そして，こ の交感神経活動の不整合性が修正された結果を服薬 前後の顔面眉間部と足趾の温度の変化として, 今回, 客観的に捉えることが出来た。服薬によって, 足趾 温度が上昇し，顔面眉間部の温度は低下する。則ち 両者間の温度差は少なくなるという結果であった。

ここでは交感神経系につてのみ言及したが，血管 作動性腸ペプチド, 一酸化窒素ほか, 血管作動物質 が多数知られており，また副交感神経のアセチルコ リンも本方証の形成に複雑に絡んでいることも忘れ てはならない。条文冒頭の「多唾口燥」は交感神経 系と副交感神経系が，同時に活動した状況を想像さ せる記述である。すなわち「多唾」は副交感神経の 活動，「口燥」は交感神経の関与を想定させる。

様々な想定・憶測は措くとして, 特に冬期におい て本方証を認識することは容易であることは事実で ある。 $10{ }^{\circ} \mathrm{C}$ 以下の外気温の環境から, 約 $27{ }^{\circ} \mathrm{C}$ に暖 房されている病院の中に入り, しかも30分以上, 待 合室で待機する。ここで，気逆傾向のある患者は， それが顕在化するのである。因みに院内の待合室で の温度を測定したところ，座位で，頭部に相当する 高さと床付近では約 $1.2{ }^{\circ} \mathrm{C}$ 差が観察された。この 温度差は外気温が低い日にはさらに大きくなり, 気 
逆が誘発されやすくなるものと考えられる。

このように本方証を理解すると, まさに「方証相 対」で, 西洋医学的病名には関わりなく, 幅広い応 用が可能になると筆者らは考えている。

\section{結論}

苓桂五味甘草湯は顔面紅潮，頭冒感，排尿困難， 下肢（四肢）厥冷を手がかりとして，顔面の皮膚疾 患, 耳鼻科疾患, 呼吸器疾患, 泌尿生殖器疾患, 神 経内科疾患に広く応用可能な方剂であることを，過 去の報告例, 自験例の検討から明らかにし, その目 標を掲げた。また本方証の形成には交感神経系活動 の部位的不整合性が関与する可能性について推論し た。

附記ここで用いた苓桂五味甘湯の構成生薬と分量 は次の通りである。

获苓 $8 \mathrm{~g}$ (中国), 桂皮 $5 \mathrm{~g}$ (中国), 五味子 $3 \mathrm{~g}$ (中 国)，甘草 $3 \mathrm{~g}$ (中国)

利益相反（COI）に関して開示すべきものなし。

\section{参考文献}

1 ) 多紀元簡. 金匱要略輯義 (影印複刻). 出版科学総合 研究所, 1979.

2 ) 芸備医学会 (吳秀三). 東洞全集 (複刻版). 思文閣出 版, 1970. 340 .
3 ) 藤平健. 類聚方広義解説. 創元社, 1999. 152-155.

4 ）長谷川弥人. 勿誤薬室「方函」「口訣」釈義. 創元社, 1985.

5 ) 和田啓十郎. 医界之鉄椎 (複刻版)。たにぐち書店, 2010.

6 ) 矢数道明. 臨床応用 - 漢方処方解説. 創元社, 1966.

7 ) 藤平健. 漢方臨床ノート・治験篇. 創元社, 1988.

8 ) 奥田謙蔵. 漢方古方要方解説. 医道の日本社, 1973. 86-88.

9 ) 山田光扸．漢方処方応用の実際．南山堂，1967. 346.

10) 湯本求真. 皇漢医学 (複刻版). 巻 $1,234-236$, 巻 3 , 225, 403, 燎原書店, 1976.

11）大塚敬節。最近の治験三例. 漢方と漢薬 $1938 ; 5$ : 235-236.

12）大塚敬節. 治験三例. 漢方と漢薬 $1940 ; 7: 1176$.

13）大塚敬節．治験五例．漢方と漢薬 $1941 ； 8: 149$.

14）大塚敬節. 漢方診療三十年. 創元社， 1959. 346.

15）諏訪重雄. 苓桂味甘湯治験 - 不治験. 漢方の臨床 $1964 ; 11: 25-27$.

16）龍野一雄．新撰類聚方．平文社， 1959．274-278.

17）龍野一雄. 治験例. 漢方の臨床 $1970 ； 17: 23$.

18）穴吹浩. 嘔気，嘔吐を伴う眩暈に苓桂味甘湯を使った 一症例. 日東医誌 $1992 ； 43 ： 109$.

19）若林研司。苓桂味甘湯の使用経験. 日東医誌 2000 ; $50(6): 117$.

20）長坂和彦, 巽武司, 名取道夫. 耳閉塞感に対する苓桂 味甘湯の使用経験. 日東医誌 $2003 ; 54$ suppl：218.

21）諸橋轍次. 大漢和辞典. 大修館書店, 1960.

22）高橋昭, 間野忠明, 菅屋潤壹, 他訳. ロバートソン自 律神経学. エルゼビア・サイエンス株式会社ミクス, 2007. 143-147. 